\title{
Passive solar design: where urban and building design meet
}

\author{
R. H. J. Looman \& M. M. E. van Esch \\ Faculty of Architecture, Delft University of Technology, The Netherlands
}

\begin{abstract}
Urban layout has a significant impact on the outdoor microclimate in the city. The urban fabric can limit solar access, but also has the ability to store and trap heat. This may lead to uncomfortable or even unhealthy situations outdoors. The indoor thermal environment can be controlled independent of dynamic outdoor conditions. However, this is undesirable from a comfortable and sustainable point of view. It is therefore preferable to find passive building strategies to support a comfortable thermal environment outdoors as well as indoors.

In temperate climates, buildings facing south are preferable, as they yield the largest solar gain in the heating season and the smallest in summer. However, south facing row houses imply east-west running streets, which have larger street irradiance in summer - possibly leading to heat stress - and a smaller street irradiance in winter compared to north-south running streets. In addition to orientation, the height to width ratio of streets is also of great importance since it defines the obstruction angle; buildings may cast shadows on the street or on the opposite building facade resulting in reduced solar gains.

The full paper discusses the viability of passive solar heating strategies in residential buildings in The Netherlands under the influence of typical urban density and layout. In addition, the paper gives some guidelines for the integration of passive solar heating strategies for dwellings in different urban situations. The effects of orientation and street width of an urban canyon on the percentage of irradiated street and facade areas, for different seasons in The Netherlands, will be discussed in another paper by the authors.
\end{abstract}

Keywords: passive solar design, urban design, solar access, building design, passive solar heating. 


\section{Introduction}

With passive solar design you benefit from the heating potential of the sun. Careful tuning of solar radiation collection, thermal conservation and diurnal storage decides to what extent solar radiation can contribute to annual space heating [1-3].

The principle of passive solar heating is based on the absorption of shortwave solar radiation by (building) materials that in turn disperse long-wave heat radiation to indoor spaces. This can be done most effectively by placing the materials exposed to the sun behind a layer of glass, for glass transmits shortwave solar radiation but reflects long-wave heat radiation. The obvious way to allow solar radiation directly into your building is to strategically place windows facing the sun and using the space to be heated as the solar collector device. The addition of thermal mass and insulation ensures that the collected heat during the daytime is sufficient to bridge diurnal cycles.

In an urban setting, solar radiation collection is interfered by shadows cast by neighbouring buildings. Urban density and layout determine the extent of this interference [4]. On street level this may lead to reduced solar access which may lead to discomfort. For buildings this implies less solar gains. In dense urban setup lower levels of the building facade are less exposed to the sun. Larger and elevated windows can compensate for this loss in solar radiation collection. In addition, different roof shapes may optimise solar exposure of the facade and the street in a specific urban setting (e.g. orientation and street width).

With the aid of building simulations both solar contribution to monthly heating and solar exposure of transparent openings distributed over the facade are studied for different building types and urban settings.

The effects of orientation and street width of an urban canyon on the percentage of irradiated street and facade area, for different seasons in The Netherlands, are discussed in another paper.

\section{Urban and building parameters}

The urban and building types as distinguished in this paper represent common practice in The Netherlands. Street width is taken from typical values for historical inner-city developments up to the 17th century city extensions, Dutch post-war low rise developments and recently developed Vinex neighbourhoods $[5,6]$. The terraced dwelling is the most common in both existing stock and new housing developments in The Netherlands [7].

\subsection{Design parameters}

Studied street widths are 10, 15, 20 and $25 \mathrm{~m}$. Two orientations are studied: eastwest running streets with the back facade facing south and north-south running streets with the back facade facing west. The back facade is the facade with the largest transparent openings. Three different roof shapes are studied: gable, shed and flat (figure 1). 
roof shape

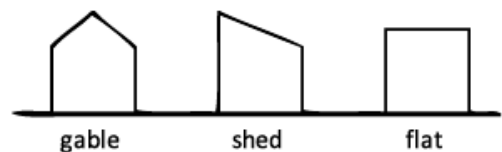

street orientation

east-west

running streets

$\hat{\mathrm{N}}$
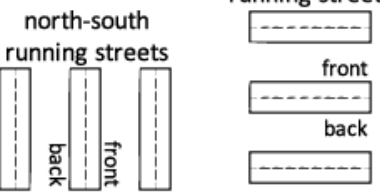

Figure 1: $\quad$ Roof shape and street orientation.

obstruction angle in a vertical plane

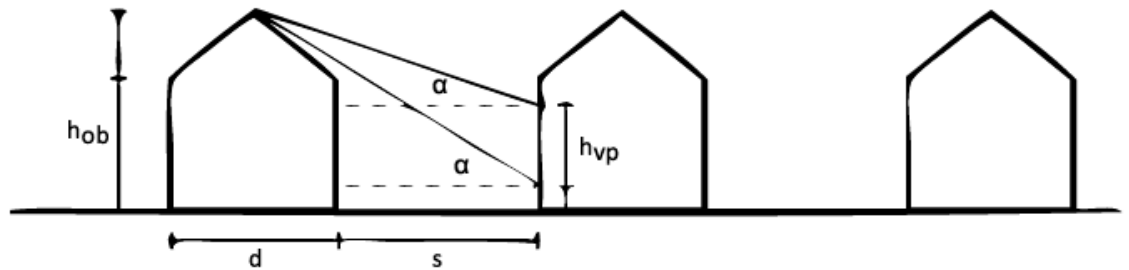

obstruction angle in a horizontal plane
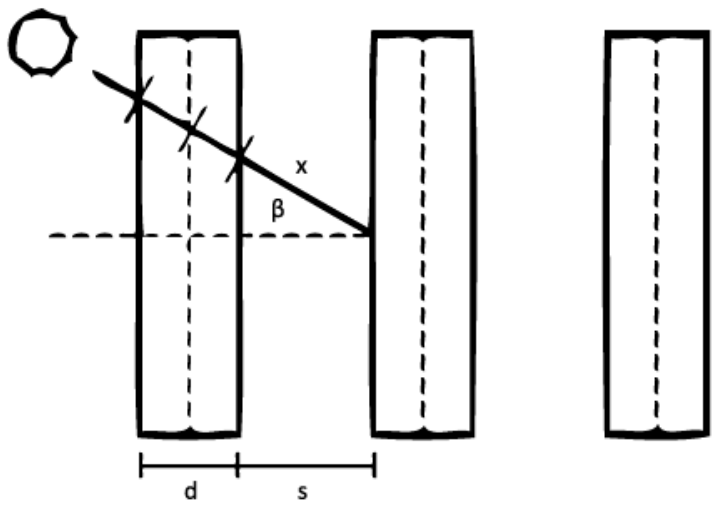

Figure 2: Determination of obstruction angles.

Figure 2 shows the obstruction angle in a vertical plane $(\alpha)$. This angle is calculated with simple trigonometry. The obstruction angle in a vertical plane depends on the street width $(\mathrm{s})$, the height $\left(\mathrm{h}_{\mathrm{ob}}\right)$ and depth $(\mathrm{d})$ of the obstruction, the shape of the roof, the distance to the obstruction $(\mathrm{x})$, the view point $\left(\mathrm{h}_{\mathrm{vp}}\right)$ and the sun's azimuth $(\beta)$.

The building shape and layout is based on a reference dwelling described by SenterNovem [7], an agency of the Dutch Ministry of Economic Affairs, and can be seen as a schematic representation of the standard of current and expected 
building design in The Netherlands. The three-storey building has a total gross floor area little over $123 \mathrm{~m}^{2}$ and a volume of approximately $428 \mathrm{~m}^{3}$. The top floor is in use as a habitable zone. The lowest and highest point of the top floor for both the gable and shed roof is respectively $5.72 \mathrm{~m}$ and $10.62 \mathrm{~m}$. The flat roof has a highest point of $8.17 \mathrm{~m}$.

The reference dwelling is constructed from massive building elements (concrete and brickwork). Furthermore it meets typical thermal insulation requirements (i.e. $\mathrm{Rc}=3.0 \mathrm{~m}^{2} \mathrm{~K} / \mathrm{W}$ for external walls and ground floor slab; $\mathrm{Rc}=$ $4.0 \mathrm{~m}^{2} \mathrm{~K} / \mathrm{W}$ for the roof construction) [8]. All transparent openings are constructed from high-efficiency double-pane glazing $\left(\mathrm{U}_{\text {glass }}=1.27 \mathrm{~W} / \mathrm{m}^{2} \mathrm{~K}\right.$; gvalue $=0.6$ ).

Improvements to enhance passive solar performance are achieved through improved thermal insulation of the opaque elements (i.e. $\mathrm{Rc}=4.0 \mathrm{~m}^{2} \mathrm{~K} / \mathrm{W}$ and $\left.\mathrm{Rc}=5.0 \mathrm{~m}^{2} \mathrm{~K} / \mathrm{W}\right)$ in order to retain collected heat within the building. In addition, solar dwelling 1 has enlarged transparent openings at the back facade and solar dwelling 2 accommodates windows at the top floor (figure 3).

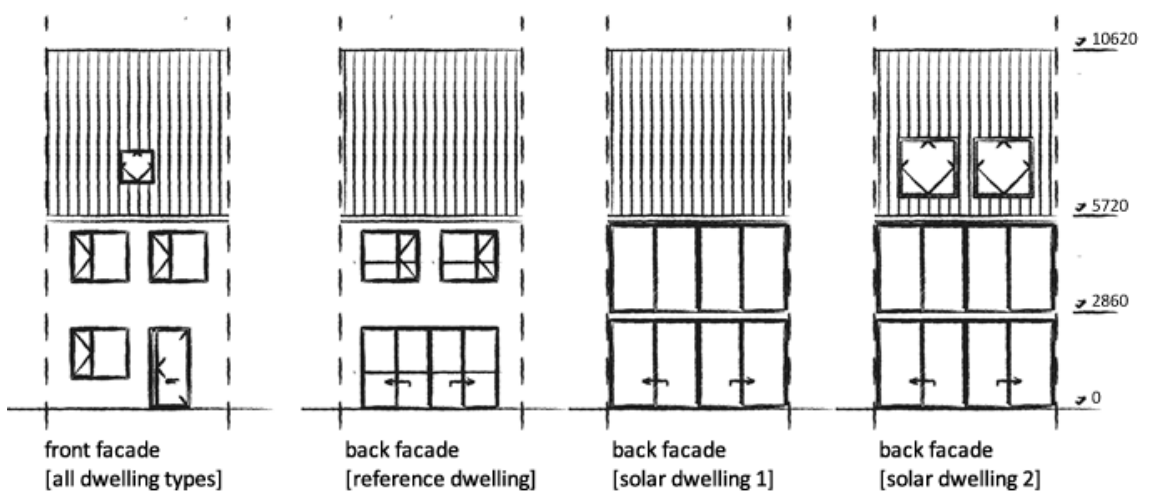

Figure 3: Typical facades of terraced dwellings (here with gable roof).

\subsection{Calculation method}

Simulations are performed with the aid of TRNSYS, a transient simulation tool that simulates thermal energy systems, such as buildings. To assure integral assessment of energy performance of different concepts, building volume and footprint are kept constant.

Building simulations are performed with reference climate data for De Bilt, The Netherlands $\left(52^{\circ} 06^{\prime} \mathrm{N}\right.$ and $\left.5^{\circ} 11^{\prime} \mathrm{E}\right)$, which contains measured data for the year 1995. The sun reaches its highest altitude of $61^{\circ}$ at noon at the start of summer and its lowest altitude of $14^{\circ}$ at noon at the start of winter. Mean ambient temperatures range from $2.2^{\circ} \mathrm{C}$ in winter to $16.9^{\circ} \mathrm{C}$ in summer.

The influence of occupancy is kept constant during simulations. Timeindependent internal heat gains and ventilation rates (based on minimal requirements) are applied together with a fixed temperature set point of $20^{\circ} \mathrm{C}$ for the habitable zones. 


\section{Results}

A total number of 90 simulations have been conducted with the four different design parameters: dwelling type, roof shape, street width and orientation. A selection of the outcomes is presented below.

\subsection{Passive solar heating contribution}

Figures 4 to 6 show passive solar heating contribution, the percentage of the heat demand that is met by solar gains, for different building types and different orientations at a street width of $15 \mathrm{~m}$.

Figure 4 shows that increased thermal conservation and enlarged transparent openings have significant impact on passive solar heating contribution. The effect is notable during the whole heating season (from October to April) with absolute increased contribution varying from 3\% to $34 \%$ (relative contribution increase varies from $86 \%$ to $153 \%$ ) for the solar dwelling 2 (sol2) compared to the reference dwelling.

Note that there is an optimum in increasing the amount of glazing in a building since typically windows are worse insulators than opaque elements. The use of thermal shutters may become beneficial here. Thermal shutters are placed in front of windows when the sun sets in order to improve its thermal resistance.

With north-south running streets the back facade of the dwelling faces west. West facing dwellings have a decreased passive solar heating contribution because the sun's altitude is lower. The absolute decrease in contribution during the heating period varies and can become up to $13 \%$ for the reference dwelling (figure 5) and up to $24 \%$ for the solar dwelling 2 (figure 6). Relative decrease can be as much as $40 \%$ for both types of dwellings. The west facing reference dwelling shows a slight increment in solar gains during May and June. This can be explained from relative high solar radiation levels for west-facing vertical planes from the used climate data set during those months in combination with the relative low sun angles when the sun is in the west.

passive solar heating contribution $/ \mathrm{s}=15 \mathrm{~m}$

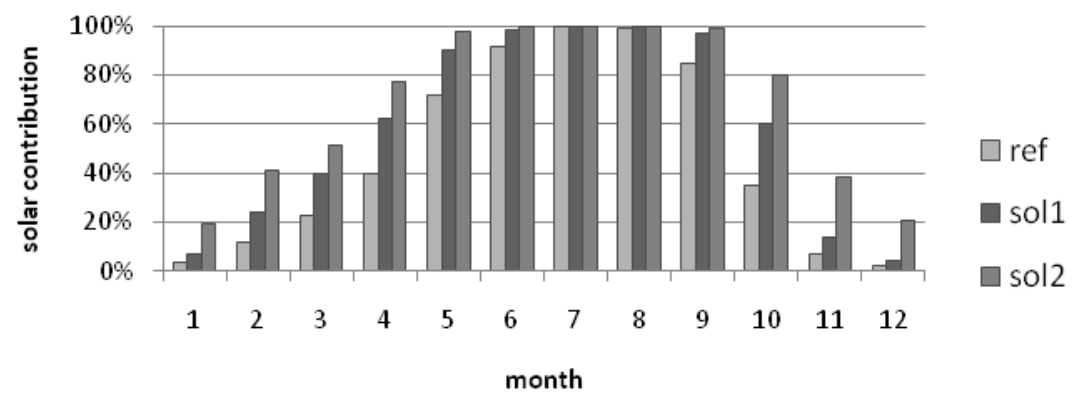

Figure 4: Passive solar heating contribution for different building types with gable roofs in east-west running streets $[\mathrm{s}=15 \mathrm{~m}]$. 


\section{passive solar heating contribution / ref $/ \mathrm{s}=15 \mathrm{~m}$}

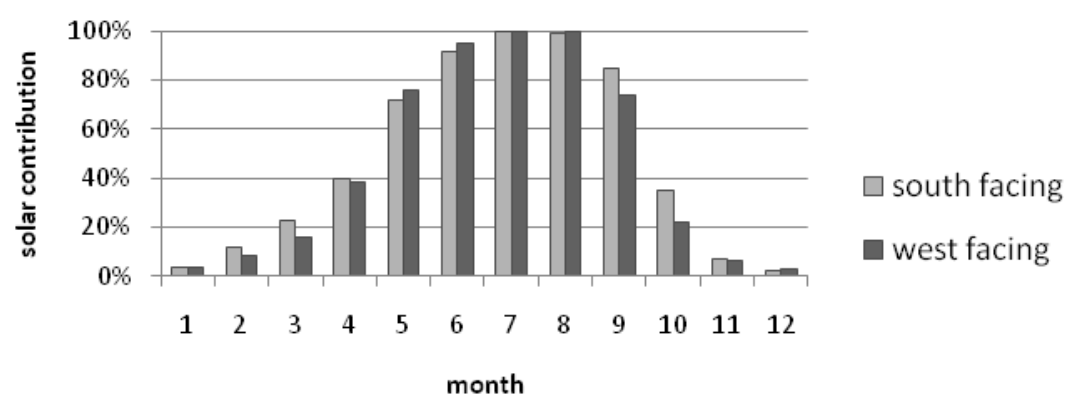

Figure 5: Passive solar heating contribution for the reference dwelling at different orientations $[\mathrm{s}=15 \mathrm{~m}]$.

\section{passive solar heating contribution / sol $2 / \mathrm{s}=15 \mathrm{~m}$}

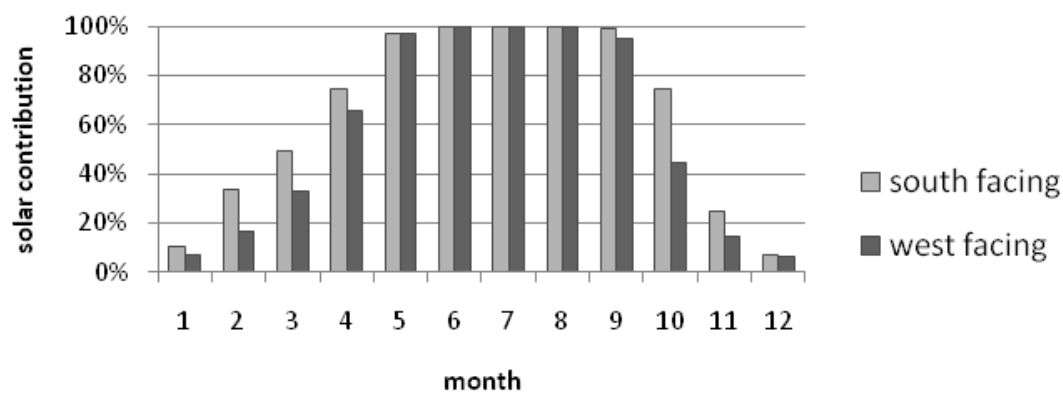

Figure 6: Passive solar heating contribution for solar dwelling 2 at different orientations $[\mathrm{s}=15 \mathrm{~m}]$.

A final remark should be made on the necessity of proper solar shading measures when designing from a passive solar heating point of view in order to prevent issues of overheating in summer. Solar contributions of $100 \%$ as seen in figures 4 to 6 indicate that solar gains are sufficient to meet heat demands. It gives no indication of possible overheating issues.

\subsection{Solar exposure of transparent openings}

Figures 7 to 12 present the solar exposure of transparent openings in a given urban setting as a fraction of solar exposure in a non-shaded situation. Figure 7 to 9 show solar exposure fractions for the ground floor for different street widths and figure 10 to 12 show solar exposure of the top floor for different street widths.

As can be seen from the figures, solar exposure increases for increasing street width in most months of the heating period. With a shed roof significant increase 
is notable at smaller street widths and at lower sun angles when compared to the gable or flat roof. This can be explained from the increased distance to the point of obstruction as it is at the far end of the building when this obstruction has a shed roof. The flat roof has a slight advantage over the gable roof at a street width of $20 \mathrm{~m}$ and $25 \mathrm{~m}$ in January and November. At increased street widths the ratio of the distance to the obstruction $(\mathrm{x})$ and its height $\left(\mathrm{h}_{\mathrm{ob}}\right)$ of flat roof shaped buildings allow lower sun angles to radiate the facade when compared to gable roof shaped buildings that have a higher obstruction height but also know a longer distance to the obstruction. No significant difference is found between the different roof types in December, when the lowest sun angles of the year occur.

Solar exposure of the top floor of the gable roofed dwelling collects less solar radiation during the heating period when compared to the shed or flat roofed dwelling. This can be explained from the fact that the windows on the top floor of a gable roof are sloped and therefore have a smaller vertical collection area that faces the sun at lower sun angles.

\section{solar exposure fraction / gable roof / ground floor}

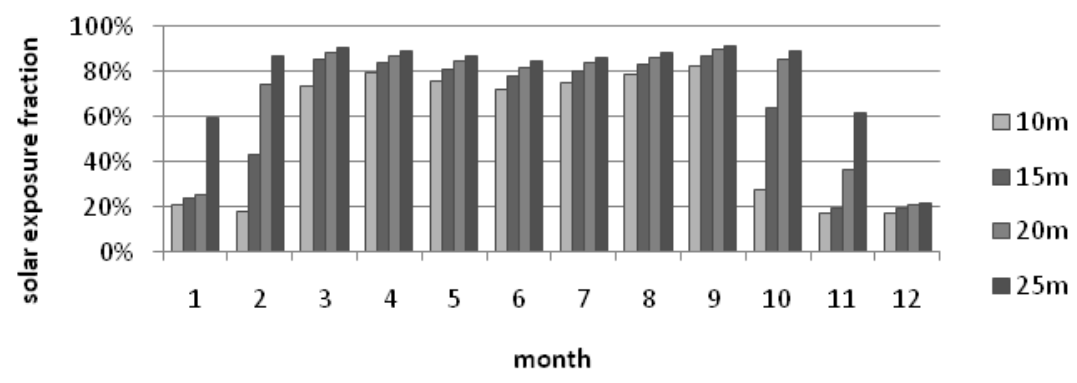

Figure 7: $\quad$ Solar exposure fraction of the ground floor of a gable roof.

\section{solar exposure fraction / shed roof / ground floor}

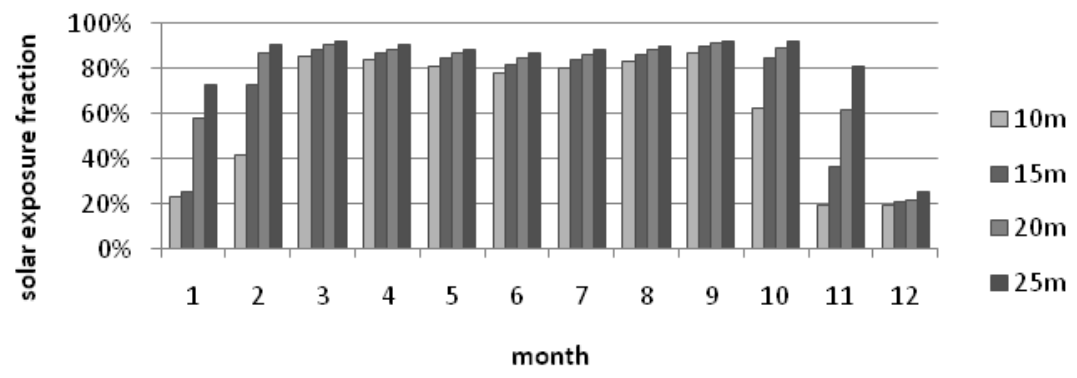

Figure 8: $\quad$ Solar exposure fraction of the ground floor of a shed roof. 


\section{solar exposure fraction / flat roof / ground floor}

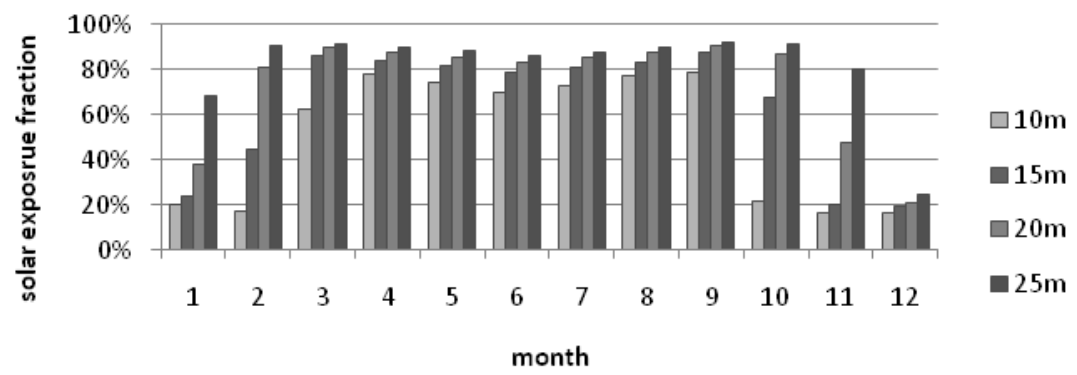

Figure 9: Solar exposure fraction of the ground floor of a flat.

solar exposure fraction / gable roof / top floor

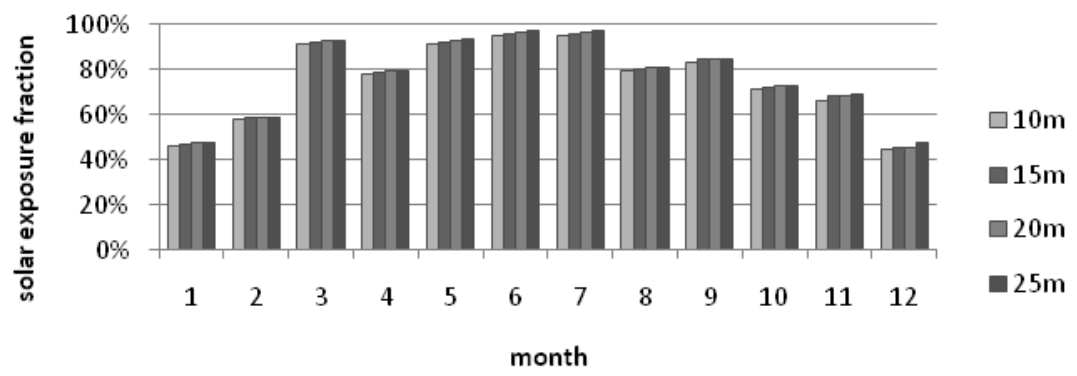

Figure 10: Solar exposure fraction of the top floor of a gable roof.

\section{solar exposure fraction / shed roof / top floor}

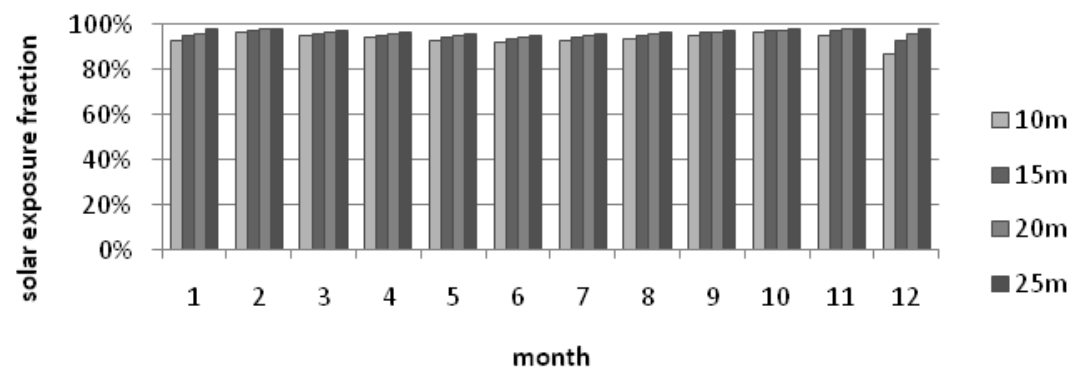

Figure 11: Solar exposure fraction of the top floor of a shed roof. 


\section{solar exposure fraction / flat roof / top floor}

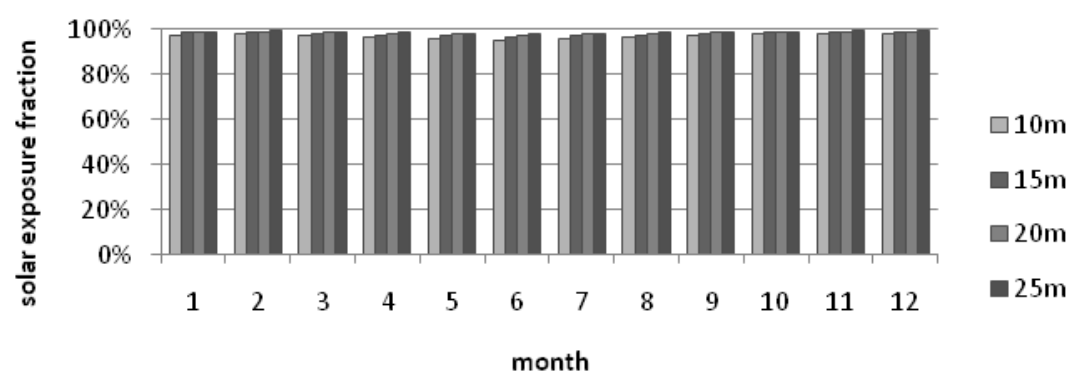

Figure 12: Solar exposure fraction of the top floor of a flat roof.

\section{percentage of irradiated street / shed roof}

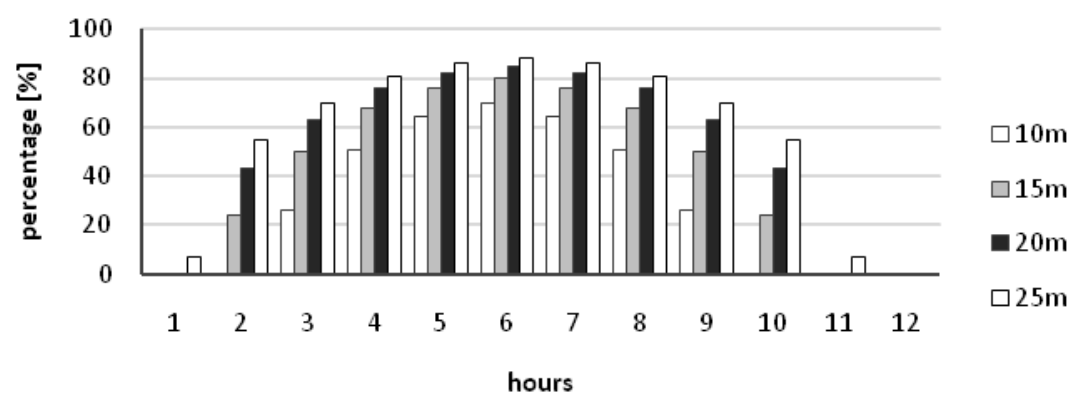

Figure 13: Percentage of irradiated street surface at noon of an east-west running street with shed roofed dwellings, for different street widths.

In order to increase the share of solar gains in an effort to meet heat demands street width can be varied between the front and back side of a building together with variable roof top design of the obstructions. These measures on the urban scale can be complemented with measures on the building scale such as high placed windows. In addition, (a part of) the top floor could be accommodated to function as a solar collector device for the whole building. Stored heat in building mass or air can be distributed throughout the building.

\subsection{Solar access of streets}

Figure 13 shows the influence of street width on the irradiation of the street. As can be expected, larger street widths yield larger percentages of irradiation. The impact decreases at larger street widths. Figure 8 also shows that the influence of street width is highest in winter and decreases towards the summer. The figure presents the results for an east-west running street lined with shed roof dwellings, but the trends are similar for the other set-ups. 


\section{Conclusions}

Larger transparent openings and improved insulation are evidently beneficial to the contribution of solar gains in meeting residential heat demand in The Netherlands. So are south facing windows (in the Northern Hemisphere).

In order to benefit from the heating potential of the sun in an urban environment, shadows cast by neighbouring objects should be kept to a minimum. From this point of view, shed roof design proofs to be beneficial over gable and flat roofs when it comes to solar exposure of lower floor levels. The advantage of shed roof design is most evident at smaller street widths $(10 \mathrm{~m}$ and $15 \mathrm{~m})$. The impact of roof design becomes of less importance at larger street widths (from $25 \mathrm{~m}$ ).

Windows at the top floor of a building are less obstructed by identically shaped buildings in their surroundings. Therefore they collect solar radiation, even at lower sun angles in winter. This makes such windows beneficial in a passive solar heating strategy.

\section{Outlook}

A next step in this research can be the examination of optimal values for orientation, street width, building roof top design and window size and position. This may help architects and urban planners in optimising their future plans from a perspective of passive solar design. In addition the knowledge can be transformed for the case of passive solar design optimisation when restructuring existing urban environments.

This knowledge can be extended with other possible impacts in an urban microclimate such as the inclusion of air flow patterns and pollution in relation to possible (natural) ventilation strategies.

\section{References}

[1] Hestnes, A.G., et al. [ed], Solar Energy Houses - strategies, technologies, examples (2nd edition), James \& James, 2003.

[2] Goulding, J.R., et al. [ed], Energy in Architecture - The European Passive Solar Handbook, B. T. Batsford, 1993.

[3] Crosbie, M.J. [ed.], The Passive Solar Design and Construction Handbook, John Wiley \& Sons, 1998.

[4] Knowles, R.L. \& Berry, R.D., Solar Envelope Concepts - moderate density building applications, Solar Energy Information Data Bank, 1980.

[5] Berghauser Pont, M. \& Haupt, P., Spacemate: the spatial logic of urban density, DUP Science: Delft, 2004.

[6] Boeijenga, J., Mensink, J., et al., Vinex atlas, 010 Publishers: Rotterdam, 2008

[7] Senternovem, Referentiewoningen nieuwbouw [in Dutch], Senternovem, 2006.

[8] Hameetman, P., Toolkit duurzame woningbouw - voor ontwikkelaars, gemeenten en ontwerpers, Aeneas: Boxtel, 2005. 